\title{
HIGH STRENGTH CONCRETE USING PURIFIED FLY ASH
}

\author{
Alankar V. Jadhav ${ }^{1}$, Ajit S. Sapkal ${ }^{2}$, M.V. Nagendra ${ }^{3}$ \\ ${ }^{1}$ Student, Civil Engineering Department, P.V.P.I.T. Budhgaon, Sangli Maharashtra India \\ ${ }^{2}$ Student, Civil Engineering Department, P.V.P.I.T. Budhgaon, Sangli Maharashtra India \\ ${ }^{3}$ Professor Civil Engineering Department, P.V.P.I.T. Budhgaon, Sangli Maharashtra India
}

\begin{abstract}
For the shelter requirements of widely spreading population civil industry also spreading enormously. With different and advanced construction techniques numbers of materials used in this construction procedure are also developed and used in general practice. Cement is base product for every type of construction. It is made from natural material with special factory procedure. This cement or cementitious material has strength up to 53 MPa. But while practicing higher grade concretes which has strength more than $65 \mathrm{MPa}$ we have to use some special processed material mixture with cement. During this material study we have to use material purified fly ash. This fly ash possess some good qualities like extra silica percentage, more fine and better surface area. So it is better option than factory waste fly ash and silica fume to achieve desired strength of concrete. With different trial mixes we can use it in general practice.
\end{abstract}

Key Words: fly ash, silica fume, super plasticizer, purified fly ash,

\section{INTRODUCTION}

Since $19^{\text {th }}$ century cement prove itself as a base construction material for every type of structure. It is famous due to its mixing ability with other reactive and inert material in cement to develop new product as per our requirements and standards. High performance concrete is a concrete mixture that has high strength and durability than conventional concrete. As different types of materials are used in modern concrete practices HPC also continues this list. This concrete mix consists of one or more cementatious material such as fly ash, silica fume, GGBS and purified or processed fly ash. Polycarboxilin ether based super plasticizers can lower w/c ratio greatly enhance strength, durability and practical properties.

\subsection{Objectives and significance}

The main objective of present study is to develop High strength concrete by varying mix proportions of replacements of mineral admixtures with varying dosage of super plasticizer and follow the provisions given in IS codes regarding mix design. Here the investigation is carried out for M100 grade concrete to produce High strength concrete using mineral admixtures to obtain good strength and workability of designed mix.

\section{MATERIAL}

2.1 Cement: Cement is the primary constituent for manufacturing concrete. Here Ordinary Portland Cement (53grade) confirming to IS12269-1987 was used. Specific gravity of cement is 3.15 .

2.2 Fine aggregate: Locally available river sand free of silt confirming to IS 383-1970 with specific gravity 2.7 is used.

2.3 Coarse aggregate: Crushed stone aggregate of 10-12 $\mathrm{mm}$ size is added from nearby quarry with specific gravity 3.01 confirming to IS 383-1970

2.4 Super plasticizing Admixture: The hyper plasticizers shall be ADDMIX 389and ADDMIX $345 \mathrm{R}$, high range water reducing, Superplasticizer based on polycarboxylic ether formulation. The products shall have specific gravities 1.08 and 1.14. Solid contents not less than $40 \%$ by weight.

2.5 Purified Fly Ash: purified fly ash is highly pozzolanicaly active in nature. It has particle size less than 45 and 25 microns. It also has high percentage of silicon. It is produced in Kupwad MIDC, sangli by SP Concare limited.

2.6 Fly Ash: This is produced from thermal power plant in the form of dry powder confirming to IS 3812-1981

2.7 Silica Fume: Silica fume is very fine non crystalline silica. It is produced in electric arc furnace having specific gravity 2.2 is used.

2.8 Water: Water used for mixing and curing should be potable and free from any harmful material.

\section{METHODOLOGY}

In this investigation we replace the cement with mineral admixture such as purified fly ash, Silica fume and Fly ash in various percentages. We take $\mathrm{W} / \mathrm{c}$ ratio in varying percentage. Here super plasticizer is used for better workability. By using cube of $150 \times 150 \times 150 \mathrm{~mm}$ size, different concrete mixes is cast and test is conducted to find compressive strength at 7 days and 28 days curing period. 


\section{Collection of Materials Materials}

Cement $=440 \mathrm{~kg} / \mathrm{m} 3$

Fly ash $=69 \mathrm{~kg} / \mathrm{m} 3$

Silica Fume $=44 \mathrm{~kg} / \mathrm{m} 3$

Water $=141 \mathrm{~kg} / \mathrm{m} 3$

Fine Aggregate $=672 \mathrm{~kg} / \mathrm{m} 3$

Coarse Aggregate $=1100 \mathrm{~kg} / \mathrm{m} 3$

Admixture $=4.74 \mathrm{lit} / \mathrm{m} 3$

Chart -1: Methodology chart

\subsection{Compression test}

The compression test on Concrete is done on the standard size of cube $150 \times 150 \times 150 \mathrm{~mm}$. The test is performed after 7and 28 days curing. The Compression strength is calculated as follows.

$\mathrm{fck}=\mathrm{P} / \mathrm{A}$

Where,

$$
\begin{gathered}
\mathrm{P}=\text { Load at Failure }(\mathrm{N}) \\
\mathrm{A}=\text { Cross sectional area }\left(\mathrm{mm}^{2}\right) \\
\mathrm{fck}=\text { Compressive Strength }\left(\mathrm{N} / \mathrm{mm}^{2}\right)
\end{gathered}
$$

\section{CONCRETE MIX DESIGN}

\section{Mix Design 1}

$15 \%$ Fly ash, $10 \%$ Silica Fume, 2\% Admixture

Cement $=581.675 \mathrm{~kg} / \mathrm{m}^{3}$

Fly ash $=116.325 \mathrm{~kg} / \mathrm{m}^{3}$

Silica Fume $=77.5 \mathrm{~kg} / \mathrm{m}^{3}$

Water $=141 \mathrm{~kg} / \mathrm{m}^{3}$

Fine Aggregate $=514.38 \mathrm{~kg} / \mathrm{m}^{3}$

Coarse Aggregate $=1133.23 \mathrm{~kg} / \mathrm{m}^{3}$

Admixture $=14.36 \mathrm{lit} / \mathrm{m}^{3}$

$\mathrm{W} / \mathrm{C}$ Ratio $=0.20$

Revised W/C Ratio $=0.18$

\section{Mix Design 2}

25\% POZZOCARE SP 45, 10\% POZZOCARE SP 25, $1.4 \%$ Admixture

Cement $=504 \mathrm{~kg} / \mathrm{m} 3$

POZZOCARE SP $45=193.88 \mathrm{~kg} / \mathrm{m} 3$

POZZOCARE SP $25=77.5 \mathrm{~kg} / \mathrm{m} 3$

Water $=141 \mathrm{~kg} / \mathrm{m} 3$

Fine Aggregate $=514.33 \mathrm{~kg} / \mathrm{m} 3$

Coarse Aggregate $=1133.23 \mathrm{~kg} / \mathrm{m} 3$

Admixture $=10.053 \mathrm{lit} / \mathrm{m} 3$

$\mathrm{W} / \mathrm{C}$ Ratio $=0.2$

Revised W/C Ratio $=0.18$

\section{Mix Design 3}

$15 \%$ Fly ash, $10 \%$ Silica fume, $0.6 \%$ Admixture

\begin{tabular}{|c|c|c|c|}
\hline \multirow[t]{2}{*}{ Sr.No } & \multirow[t]{2}{*}{ Mix Proportions } & \multicolumn{2}{|c|}{$\begin{array}{l}\text { Compressive strength a } \\
7 \text { days }\end{array}$} \\
\hline & & fck & Average fck \\
\hline $\mathrm{A}]$ & $\begin{array}{l}\text { M100+15\% Fly } \\
\text { ash }+10 \% \text { Silica } \\
\text { Fume }+2 \% \text { Admix- } \\
389\end{array}$ & \begin{tabular}{|l|}
57.7 \\
62.3 \\
57.5
\end{tabular} & 59.16 \\
\hline B] & $\begin{array}{lr}\text { M100 }+ & 15 \% \\
\text { POZZOCARE } & \text { SP } \\
45+ & 10 \% \\
\text { POZZOCARE } & \text { SP } \\
25+0.6 & \% \\
\text { Addmix-345R } & \end{array}$ & \begin{tabular}{|l|}
57.4 \\
57 \\
56.9
\end{tabular} & 57.1 \\
\hline C] & $\begin{array}{lr}\text { M100 }+ & 25 \% \\
\text { POZZOCARE } & \text { SP } \\
45 \quad+\quad 10 \% \\
\text { POZZOCARE } \\
25+1.4 \quad \text { SP } \\
\text { Addmix-345R }\end{array}$ & \begin{tabular}{|l|}
60.3 \\
58.9 \\
62.6
\end{tabular} & 60.6 \\
\hline
\end{tabular}

$\mathrm{W} / \mathrm{C}$ Ratio $=0.25$

Table -1: Compressive strength at 7 days

Table -2: Compressive strength at 28 days

\begin{tabular}{|l|l|l|l|}
\hline Sr.No & Mix Proportions & \multicolumn{2}{|l|}{$\begin{array}{l}\text { Compressive strength at } \\
\text { 28 days }\end{array}$} \\
\cline { 3 - 4 } & & fck & Average fck \\
\hline A] & $\begin{array}{l}\text { M100 + 15\% Fly } \\
\text { ash }+10 \% \text { Silica } \\
\text { Fume +2\% Admix- } \\
389\end{array}$ & 70.1 & \\
\cline { 3 - 4 } & & 60.2 & \\
& & & \\
\end{tabular}




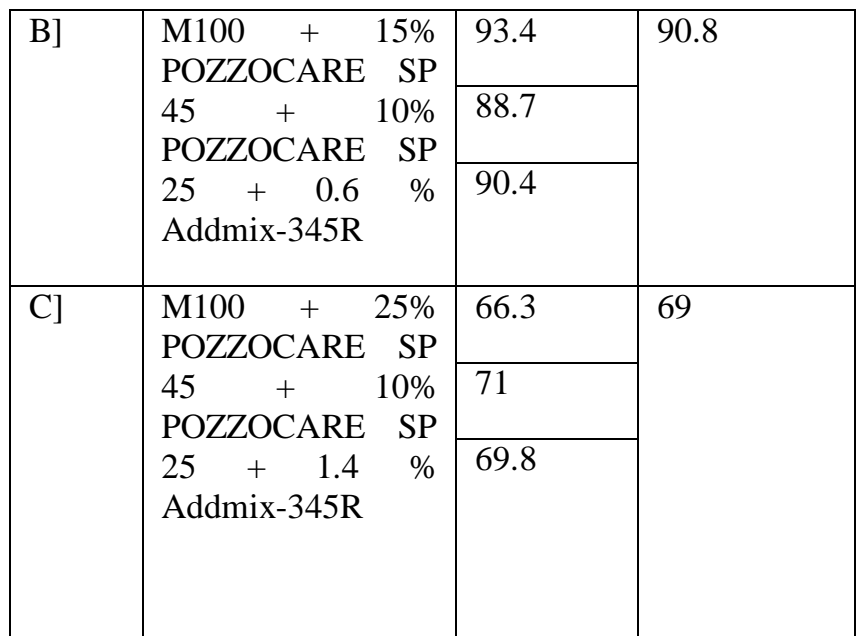

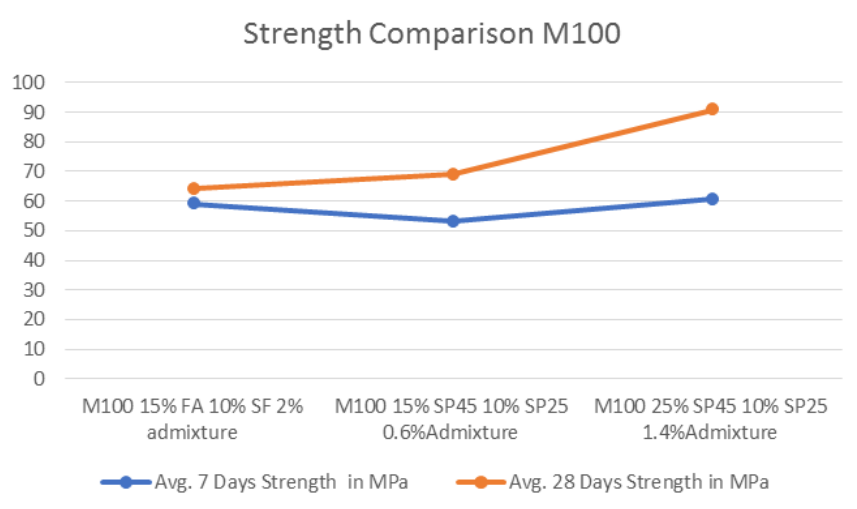

Chart - Compressive strength at 7 and 28 days

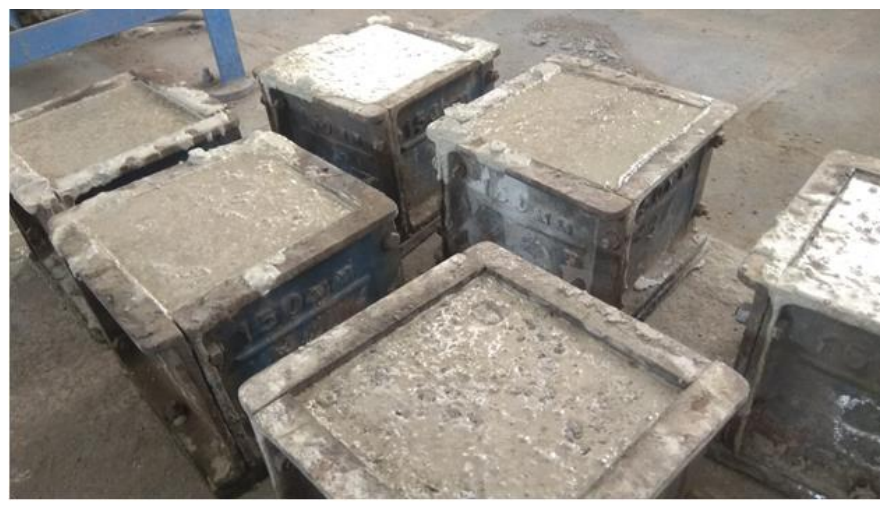

Fig -1 : Casting of Concrete blocks

\section{CONCLUSIONS}

- As w/c ratio is low super plasticizer is required for better workability.

- For High strength concrete $8-10 \mathrm{~mm}$ size coarse aggregate gives better results than $20 \mathrm{~mm}$ size aggregate.

- For higher the strength of concrete lower the w/c ratio required.

- $\quad$ The max strength achieved at 28 days is $90.8 \mathrm{Mpa}$ with replacement of mineral admixture $25 \%$ POZZOCARE $45+10 \%$ POZZOCARE 25 to cement.
- The percentage of mineral admixtures such as POZZOCARE 45, POZZOCARE 25 are gives better results in combination of two admixtures than single.

- It observed that workability of concrete decreases when adding mineral admixtures.

- The optimum dosage of replacement mineral admixtures to cement is $30-35 \%$

\section{REFERENCES}

1] Investigation of High-Strength Concrete Using FlyAsh and Silica Fume

Dr. Rakesh Srivastava1, Yogendra Kumar, Rupesh Kumar, Saurabh Kumar,

Sonam Gupta, Vijay Kumar and Vividh Mahajan

Department of Civil Engineering, Ajay Kumar Garg Engineering College, 27 Kmstone, NH-24,

Adhyatmik Nagar, Ghaziabad 201009 UP India.

2] "Strength Development Characteristics Of High Strength Concrete Incorporaing An Indian Fly Ash"(Arka Saha, Dr. Samaresh Pan, Soumen Pan) international journal of technology enhancements and emerging engineering research, vol 2, issue 6101 issn 2347-4289/2014

3]"High Strength Concrete using Supplementary Cementing Materials and Chemical Admixtures"(Dr. M. VijayaSekhar Reddy, Dr.M. C. Nataraja Dr. I. V. Ramana Reddy, J. Rajendra Prasad M. Seshalalitha)The Masterbuilder March 2015/Investigation: High strength Concrete

4] "Strengthining effect in high strength Silica fume Concrete" (Vijay Agarwal, Rajesh Gupta, Ajaykumar Gautam) International Journal of Advances in Mechanical and Civil Engineering, ISSN: 2394-2827 Volume-3, Issue-4, Aug.2016

5] Design of high strength concrete M100 by using silica fume and super plasticizers. (Karumanchi Meeravali(Assistant professor)Avula Gopikris(Assistant Professor), Regulagunta Madhu( B.Tech Student), Vipparla Veera Brahmachari( B.Tech Student)

6] Design of M100 Grade Concrete ( ACI Method) (A. Sreenivasulu , K. Srinivasa Rao Department of civil Engineering , PVP Siddhartha Institute of Technology, Vijaywada. Department of civil Engineering, college of Engineering, Andhra University, Visakhapatnam.)

7] Analysis on Mix Design of High Strength Concrete (M100) ( Ankit Kumar Vardhan1, Himanshu Johri2, Nitin Gupta3. B.Tech student $3^{\text {rd }}$ year, Department of civil Engineering ABES Engineering college Ghaziabad, Ghaziabad-201009)

8) Experiment Investing on High Performance Concrete using silica fume and Super plasticizer.

(P. Vinayagam 